\title{
Late Neogene benthic stable isotope record of Ocean Drilling Program Site 999: Implications for Caribbean paleoceanography, organic carbon burial, and the Messinian Salinity Crisis
}

\author{
Torsten Bickert \\ Fachbereich Geowissenschaften, Universität Bremen, Bremen, Germany \\ Gerald H. Haug \\ GeoForschungsZentrum Potsdam, Potsdam, Germany \\ Ralf Tiedemann \\ GEOMAR, Universität Kiel, Kiel, Germany
}

Received 19 April 2002; revised 16 October 2003; accepted 1 December 2003; published 17 March 2004.

[1] We report on epibenthic foraminiferal $\delta^{18} \mathrm{O}$ and $\delta^{13} \mathrm{C}$ and percentage coarse fraction records from Caribbean Ocean Drilling Program (ODP) Site $999\left(12^{\circ} 44^{\prime} \mathrm{N}, 78^{\circ} 44^{\prime} \mathrm{W}\right.$, water depth $\left.2828 \mathrm{~m}\right)$ spanning the interval from 8.5 to $5.3 \mathrm{Ma}$. Low epibenthic $\delta^{13} \mathrm{C}$ values and low amounts of sand-sized particles (mostly foraminifer shells) indicate a poorly ventilated deep Caribbean throughout the late Miocene. At this time the deep Caribbean was dominated by a nutrient-rich and corrosive water mass. A generally constant $\delta^{13} \mathrm{C}$ gradient between the Caribbean and deep Atlantic records during the late Miocene suggests that the fluctuations in $\delta^{13} \mathrm{C}$ reflect global changes in $\delta^{13} \mathrm{C}$ of the dissolved inorganic carbon due to varying erosion of organic carbon from terrigenous soils and shelf sediments. The observed $100-\mathrm{kyr}$ cyclicity of epibenthic $\delta^{13} \mathrm{C}$ is in good accordance with the variability of terrigenous input to the equatorial Atlantic as recorded by magnetic susceptibility records of the Ceara Rise. However, some short-term gradient changes between 7.0 and 4.5 Ma indicate a poorer ventilation of the deep Atlantic related to a reduced production of deep water in the Atlantic. The Messinian Salinity Crisis between 6.0 and $5.3 \mathrm{Ma}$ did not affect the intermediate to deep water gradient between the Caribbean and the Atlantic. Comparison to the Bahama platform record of ODP Site 1006, however, indicates a poorer ventilation of the shallower northern Caribbean basins coincident with the isolation of the Mediterranean Sea. INDEX TERMS: 4870 Oceanography: Biological and Chemical: Stable isotopes; 9325 Information Related to Geographic Region: Atlantic Ocean; 9604 Information Related to Geologic Time: Cenozoic; KEYWORDS: Neogene, Caribbean, paleoceanography

Citation: Bickert, T., G. H. Haug, and R. Tiedemann (2004), Late Neogene benthic stable isotope record of Ocean Drilling Program Site 999: Implications for Caribbean paleoceanography, organic carbon burial, and the Messinian Salinity Crisis, Paleoceanography, 19, PA1023, doi:10.1029/2002PA000799.

\section{Introduction}

[2] The late Neogene closure of the seaway between the North and South American continents is thought to have caused extensive changes in ocean circulation and Northern Hemisphere climate [Keigwin, 1982; Mikolajewicz and Crowley, 1997]. The timing and consequences of the emergence of the Isthmus of Panama with respect to ocean circulation have been addressed in several papers [Keigwin, 1982; Tiedemann and Franz, 1997; Haug and Tiedemann, 1998; Billups et al., 1999; Haug et al., 2001]. They presented planktic and benthic stable isotope and carbonate coarse fraction records from the Caribbean Sea and the open western equatorial Atlantic (Ceara Rise). These records, when compared to others from the Pacific, indicate that the closure caused a marked reorganization of surface and deep ocean circulation starting 4.6 Myr ago. Shallowing of

Copyright 2004 by the American Geophysical Union. 0883-8305/04/2002PA000799 the seaway intensified the Gulf Stream and introduced warm and saline waters to high northern latitudes, favoring early Pliocene warming of the Northern Hemisphere. The evaporative cooling of surface waters during North Atlantic Deep Water (NADW) formation would have introduced moisture to the Northern Hemisphere, which has been proposed as the necessary precondition for ice sheet growth.

[3] In contrast, the biogeographic development of marine faunas and floras on both sides of the Isthmus of Panama suggests that paleoceanographic changes related to the closing of the isthmus started much earlier. On the basis of benthic foraminiferal biostratigraphy of the Atrato Basin in northern Colombia, Duque-Caro [1990] suggested a shoaling and partial emergence of the Isthmus of Panama in the middle Miocene (at about 13-12 Ma). Recent investigations of nannofossil assemblages by Kameo and Sato [2000] showed a weakening of the circumequatorial current beginning near the middle to late Miocene boundary (about 10.7-9.3 Ma). Jackson et al. [1993] observed a radiation of mollusk species at about $7.8 \mathrm{Ma}$, while earliest 
divergences in planktonic foraminiferal faunas occurred in the late Miocene (about 6.2 Ma [Keller et al., 1989]).

[4] To further complicate cause-effect interpretations, the closing history of the Panama Seaway overlaps with the tectonic evolution of other ocean gateways in the late Miocene, especially the closure of the Strait of Gibraltar, which led to a transient isolation of the Mediterranean Sea from the Atlantic Ocean, known as the Messinian Salinity Crisis [Hsü et al., 1973]. During this period the Mediterranean desiccated several times so that large volumes of evaporites were deposited. The deposition of these salts could have removed more than $6 \%$ of all dissolved salt in the world oceans and turned them less alkaline, causing undersaturation with respect to calcium carbonate and more extensive carbonate dissolution in the deep oceans [Ryan, 1973]. Zhang and Scott [1996] even suggested that deep water turbidites observed in Labrador Sea sediments may be linked to the dessication events in the Mediterranean. The application of the orbital tuning technique by Krijgsman et al. [1999] has resulted in an exact dating of the salinity crisis. The onset occurred synchronously over the entire Mediterranean Basin at $5.96 \pm 0.02 \mathrm{Ma}$. Isolation from the Atlantic Ocean was established at 5.59 Ma. The beginning of the Pliocene is equated with the reestablishment of normal marine conditions in the Mediterranean Sea at 5.33 Ma, termed the "Terminal Messinian Flood" [McKenzie et al., 1999]. The sedimentary expression of this event is the deposition of the Zanclean pelagic succession on top of the Messinian "Lago Mare" evaporative sequence [Ryan, 1973].

[5] A pronounced flooding event at the Miocene/Pliocene boundary has also been observed on the Bahama platform. Shallow water drilling on the platform top combined with seismic studies indicates that the loci of early Pliocene reef growth moved toward the platform interior, implying that a rapid rise in sea level caused the rapid back stepping [Eberli et al., 1997]. Correlation to pelagic sediments at Ocean Drilling Program (ODP) Site 1006 located westward of the Great Bahama Bank (Figure 1) implies that the flooding of the Bahamas appears to have been synchronous with the Terminal Messinian Flood in the Mediterranean [McKenzie et al., 1999].

[6] The question arises as to how these late Miocene events are linked to the circulation in the Caribbean Sea and to related changes in the thermohaline circulation of the deep ocean. The purpose of the study was therefore (1) to present a detailed chronology for the late Miocene Caribbean Sea, (2) to reconstruct the late Neogene intermediate and deep water circulation of the Caribbean in relation to the closing history of the Isthmus of Panama and the development of the thermohaline circulation, and (3) to discuss the results in terms of Messinian climatic changes expressed by the Mediterranean Salinity Crisis.

\section{Background}

[7] The semienclosed nature of the Caribbean Sea acts as a discriminating valve for inflowing water masses. The Caribbean's connection to the deep Atlantic Ocean is restricted by sills extending from Venezuela to the Greater Antilles. Today, the nutrient-depleted high- $-\delta^{13} \mathrm{C}$ upper part
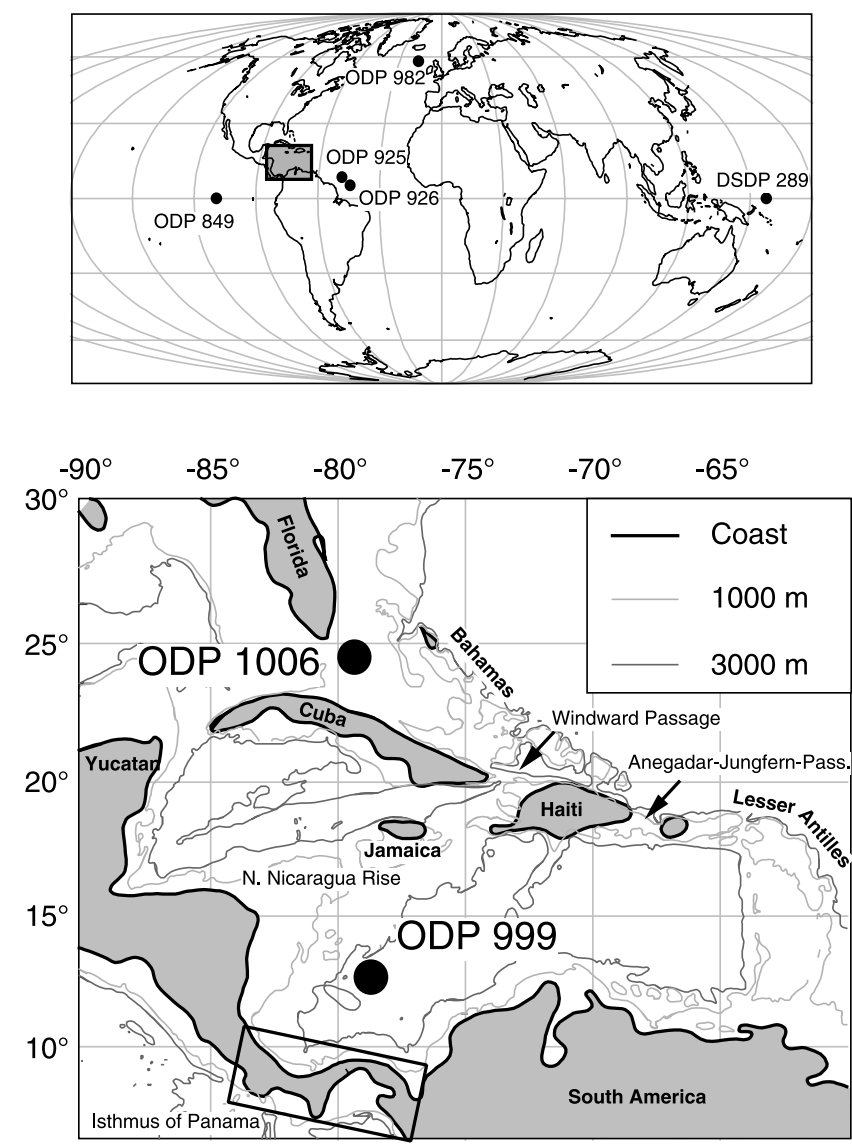

Figure 1. Locations of ODP Site 999 and other sites cited in this paper.

of North Atlantic Deep Water (UNADW), including the Mediterranean Overflow Water, enters the Caribbean Sea through the deepest sills, the Anegada-Jungfern Passage at $1800 \mathrm{~m}$ and the Windward Passage at $1540 \mathrm{~m}$ (Figure 1). Nutrient-enriched low- $\delta{ }^{13} \mathrm{C}$ Antarctic Intermediate Water (AAIW) flows at depths of $800-1400 \mathrm{~m}$, overriding the UNADW, and mixes with UNADW upon entering the Caribbean just above sill depth (for a summary, see Haddad and Droxler [1996]). This mixture then fills the lower reaches of the Caribbean basins. During the past $2.5 \mathrm{Myr}$ the relative portions of northern to southern component water masses were related to glacial-interglacial differences in the formation rate of UNADW [Oppo et al., 1995]. A weaker UNADW formation during interglacials led AAIW to extend farther north and resulted in a less ventilated, more corrosive Caribbean deep water. Hence the Caribbean Sea is a highly sensitive recorder of ventilation changes in the upper Atlantic Ocean if the sill depth remained constant. Tectonic evidence from the Lesser Antilles arc and the Aves Ridge suggests only small vertical movements of a few meters per million years [Driscoll and Diebold, 1999] since the middle Miocene (15 Ma), when a thick crust was established.

[8] According to Droxler et al. [1998], three major tectonic events modified the circulation in the Caribbean during the Neogene. Prior to the middle Miocene the 
Table 1. Site Locations

\begin{tabular}{lllc}
\hline \multicolumn{1}{c}{ Site } & Latitude & Longitude & Water Depth, m \\
\hline ODP 999 (Caribbean Sea) & $12^{\circ} 44^{\prime} \mathrm{N}$ & $78^{\circ} 44^{\prime} \mathrm{W}$ & $2828^{\mathrm{a}}$ \\
ODP 1006 (Bahamas margin) & $24^{\circ} 24^{\prime} \mathrm{N}$ & $79^{\circ} 27^{\prime} \mathrm{W}$ & 658 \\
ODP 982 (North Atlantic) & $57^{\circ} 31^{\prime} \mathrm{N}$ & $15^{\circ} 52^{\prime} \mathrm{W}$ & 1134 \\
ODP 925 (tropical Atlantic) & $04^{\circ} 12^{\prime} \mathrm{N}$ & $43^{\circ} 29^{\prime} \mathrm{W}$ & 3042 \\
ODP 926 (tropical Atlantic) & $03^{\circ} 43^{\prime} \mathrm{N}$ & $42^{\circ} 54^{\prime} \mathrm{W}$ & 3598 \\
DSDP 289 (west tropical Pacific) & $00^{\circ} 30^{\prime} \mathrm{S}$ & $158^{\circ} 31^{\prime} \mathrm{E}$ & 2206 \\
ODP 849 (east tropical Pacific) & $00^{\circ} 11^{\prime} \mathrm{N}$ & $110^{\circ} 31^{\prime} \mathrm{W}$ & 3851 \\
\hline
\end{tabular}

${ }^{\mathrm{a}}$ Caribbean Sea sill depth today is $1540-1800 \mathrm{~m}$.

${ }^{\mathrm{b}}$ DSDP is Deep Sea Drilling Project.

circumtropical current flowing from the North Atlantic to the eastern Pacific was well developed. At this time the Northern Nicaragua Rise separated the Cayman Trough and the Yucatan Basin from the Caribbean Sea. As a first event, the Central American Seaway began to shoal at about 13$12 \mathrm{Ma}$, and the deep water connection between the Caribbean and the eastern Pacific was cut off, though a circumtropical current still existed. Because of the subsidence of the Northern Nicaragua Rise a western boundary current within the Caribbean region developed in the middle Miocene. The third event was the emergence of the Isthmus of Panama in the Pliocene, which ended with the final closure of the Central American Seaway at 2.7 Ma [Kameo and Sato, 2000], coincident with the sea level drop during the onset of major Northern Hemisphere glaciation in isotope stage G6.

\section{Methods}

[9] We report on epibenthic foraminiferal $\delta^{18} \mathrm{O}$ and $\delta^{13} \mathrm{C}$ and percentage coarse fraction records from ODP Site 999 $\left(12^{\circ} 44^{\prime} \mathrm{N}, 78^{\circ} 44^{\prime} \mathrm{W}\right.$, water depth $\left.2828 \mathrm{~m}\right)$ spanning the interval from 8.5 to $5.3 \mathrm{Ma}$. ODP Hole 999A sediment cores $18 \mathrm{H}$ through $26 \mathrm{X}$ from 159.65 to 239.04 meters below seafloor (mbsf) were sampled every $10 \mathrm{~cm}$. Cibicidoides wuellerstorfi tests from each sample were analyzed on a Finnigan MAT 252 mass spectrometer at Bremen with a reproducibility $( \pm 1 \sigma)$ of $0.07 \%$ for $\delta^{18} \mathrm{O}$ and $0.05 \%$ o for $\delta^{13} \mathrm{C}$ (all values reported relative to Vienna Peedee belemnite). We compare our $\delta^{13} \mathrm{C}$ data with data from other sites on the Bahama platform (Site 1006 [McKenzie et al., 1999]), in the intermediate depth northeast Atlantic (ODP Site 982 [Hodell et al., 2001], and in the deep equatorial Atlantic (ODP Site 925 [Billups et al., 1997] and ODP Site 926 [Bickert et al., 1997b; Tiedemann and Franz, 1997; Shackleton and Hall, 1997]) (Figure 1 and Table 1). The $\delta^{13} \mathrm{C}$ values of epibenthic foraminifers are a proxy for deep water ventilation as the $\delta^{13} \mathrm{C}$ of seawater is closely linked to nutrient and oxygen levels, with higher $\delta^{13} \mathrm{C}$ values indicating lower nutrient concentrations and better ventilation (for a recent summary, see Mackensen and Bickert [1999]). Site 926 data of Shackleton and Hall [1997] contain measurements of Uvigerina sp. and other species, but all other data mostly utilize Cibicidoides spp. A correction of $+0.64 \%$ o [Duplessy et al., 1984] was applied to all Cibicidoides spp. $\delta^{18} \mathrm{O}$ data. Age models of all records were adjusted if needed to be consistent with the timescale of Shackleton and Crowhurst [1997].
[10] Coarse fraction contents were obtained in all cores through wet sieving of $8-\mathrm{cm}^{3}$ bulk sediment over a $63-\mu \mathrm{m}$ mesh sieve. Samples were then dried and weighed to determine the weight percent of sand-sized particles. The coarse fraction of deep-sea carbonates decreases as dissolution progresses [Berger et al., 1982]. The reason is that foraminiferal shells are weakened by dissolution and tend to break down in small fragments. Subsequently, material moves from the coarse fraction into finer fractions. Thus a decrease in coarse fraction content is a sensitive indicator of increasing carbonate dissolution. ${ }^{1}$

\section{Age Model}

[11] The age model of Site 999 is based on $\delta^{18} \mathrm{O}$ stratigraphy (Figure 2), which was correlated to the astronomically dated $\delta^{18} \mathrm{O}$ record from North Atlantic Site 982 [Hodell et al., 2001] and western equatorial Atlantic Site 926 [Shackleton and Crowhurst, 1997; Shackleton and Hall, 1997]. Prior to this correlation the age model of Site 982 was slightly adjusted to that of Site 926 because of a few incoherencies with respect to obliquity. Because there was no paleomagnetic chronology available for the late Miocene of Site 999 because of the difficulty of completely removing the secondary magnetization overprint [Sigurdsson et al., 1997], the correlation started from the few biostratigraphic datums given by the shipboard scientific party of Leg 165 (Figure 3). All originally published ages were converted to the new calibration of bioevents for the late Miocene by Backman and Raffi [1997], which are adjusted to the astronomically dated timescale of Shackleton and Crowhurst [1997]. Prior to $\delta^{18} \mathrm{O}$ correlation the depth scale of Site 999 was corrected for the sediment expansion after recovery by a factor of 0.9 relative to the meters below seafloor level on top of each core. This factor is taken from the observations of the multiple drilled sites of Leg 154, where gaps on the order of $10 \%$ of the core length occurred at all sites.

[12] As a result, we obtained a detailed chronology for the late Miocene interval of Site 999 with a resolution of at least one obliquity period. It is consistent with the biostratigraphy within a range of $\pm 0.1 \mathrm{Myr}$, except for the first occurrence of Amaurolithus sp., which was found to occur some $0.59 \mathrm{Myr}$ later than given by shipboard chronology. The sedimentation rate is on the order of $24.7 \mathrm{~m} \mathrm{Myr}^{-1}$, slightly lower than the Pliocene rate of $29.0 \mathrm{~m} \mathrm{Myr}^{-1}$ [Haug and Tiedemann, 1998]. The 10-cm sample spacing therefore corresponds to an average time resolution of 4050 years.

\section{Results}

[13] Figure 2 shows the benthic $\delta^{18} \mathrm{O}$ and $\delta^{13} \mathrm{C}$ data of Site 999 versus age for the late Miocene interval between 8.5 and $5.3 \mathrm{Ma}$. The $\delta^{18} \mathrm{O}$ values vary between $1.8 \%$ and $2.9 \%$ and are generally lower than the Holocene mean of 2.75\% . The absence of Northern Hemisphere continental glaciation can explain only a part of this difference. The amplitude of the variations is typically about $0.4 \%$, clearly

\footnotetext{
${ }^{1}$ Auxiliary data are available electronically at the World Data Center-A for Paleoclimatology, NOAA/NGDC, 325 Broadway, Boulder, CO, 80303 (paleo@mail.ngdc.noaa.gov; URL: http://www.ngdc.noaa.gov/paleo/).
} 

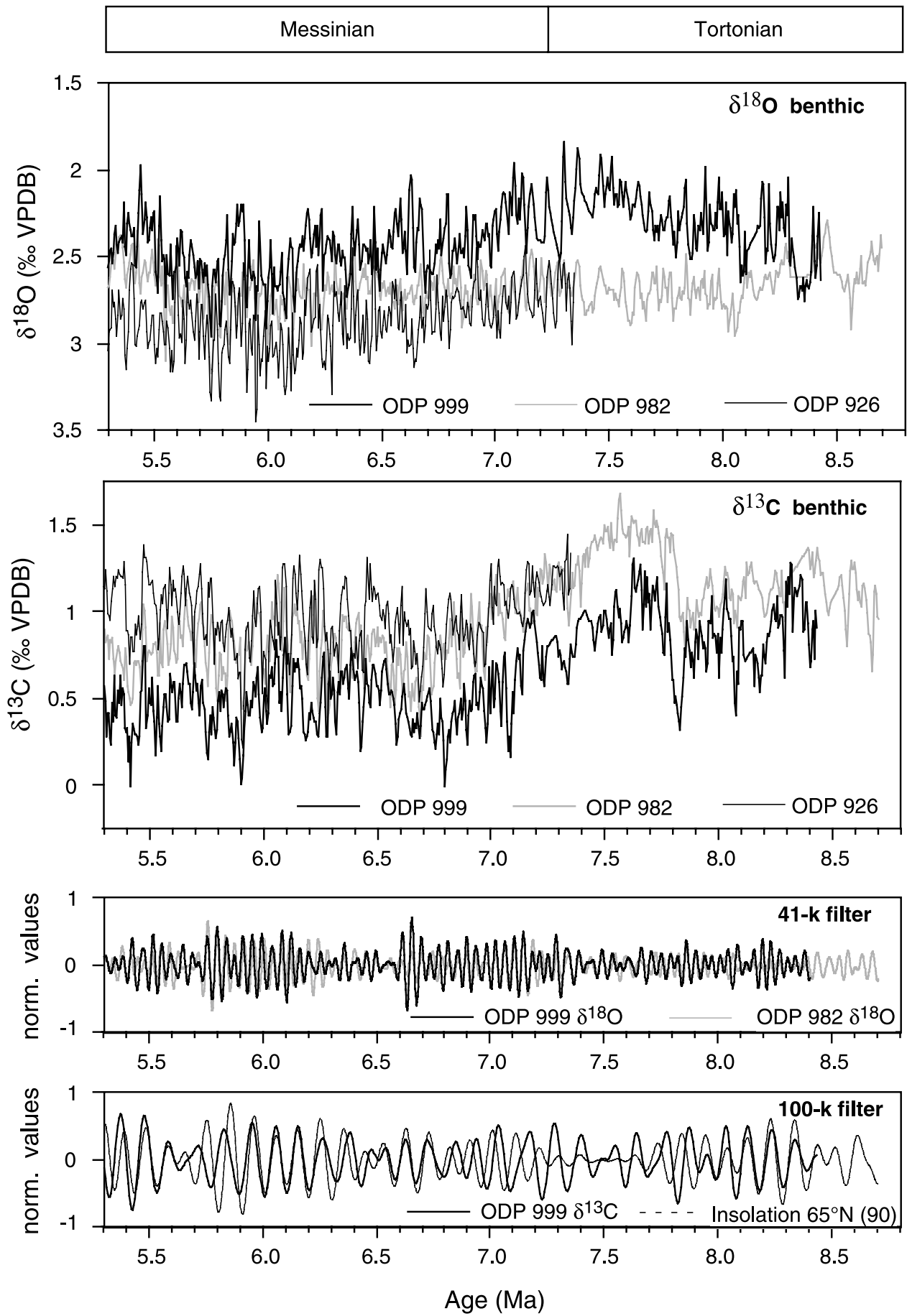

Figure 2. Benthic foraminiferal oxygen and carbon isotope records of ODP Sites 999 (this study), 982 [Hodell et al., 2001], and 926 [Shackleton and Hall, 1997]. This study focuses on the interval between 8.5 and 5.3 Ma. As a control for the age model based on the correlation of oxygen isotope records, we added the 41-kyr band-pass filter of oxygen isotope records. As a result, a distinct 100-kyr cycle became evident in the carbon isotope record of Site 999 sediments.

below the glacial-interglacial amplitudes known from the late Pleistocene [Oppo et al., 1995]. The $\delta^{18} \mathrm{O}$ cyclicity shows a weak but significant correspondence to the orbital band of obliquity, but there are many additional fluctuations which do not fit to changes in insolation. For example, there is a long-term increase from 7.5 $\mathrm{Ma}$ on, followed by a decrease starting at $5.7 \mathrm{Ma}$, with a pronounced minimum at $5.45 \mathrm{Ma}$. This decrease in $\delta^{18} \mathrm{O}$ clearly occurs before the terminal flooding event of the Messinian, as already stated by Vidal et al. [2000]. Studying a late Miocene record of the 


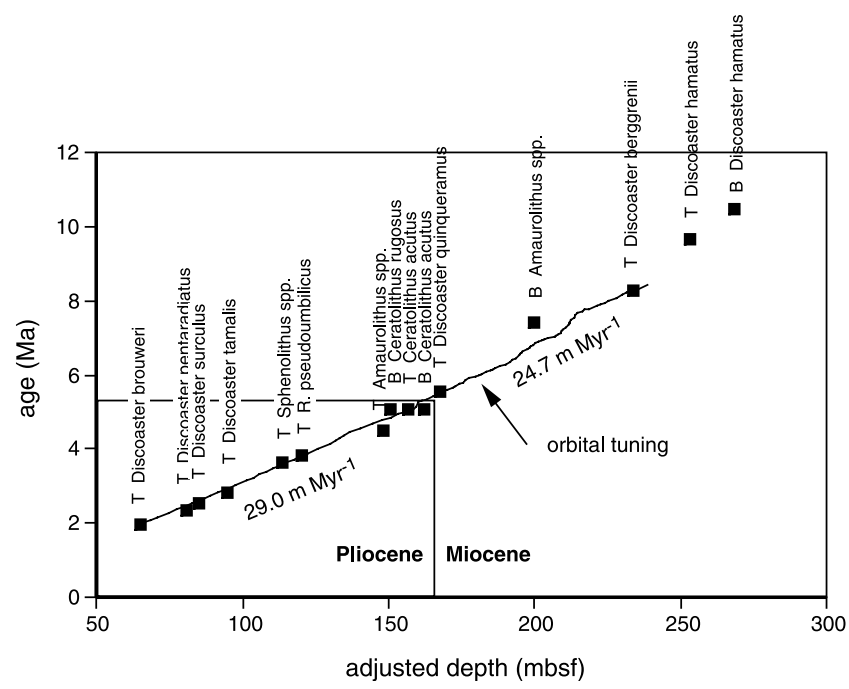

Figure 3. Age versus depth diagram of the orbitally tuned isotope record in comparison to the shipboard biostratigraphic datums based on nannofossil events. The depth scale is adjusted for the sediment extension after recovery by a factor of 0.9 relative to mbsf on top of each core.

eastern South Atlantic, they suggested that the rapid decrease in $\delta^{18} \mathrm{O}$ from 5.56 Ma on may reflect a warming of deep water temperature associated with a global warming period. This is consistent with an increase in deep Atlantic $\mathrm{Mg}$ temperatures by $1^{\circ} \mathrm{C}$ at about that time, as demonstrated by Lear et al. [2003]. Also, the $0.2-0.3 \%$ higher $\delta^{18} \mathrm{O}$ values at deep Atlantic Site 926 relative to Caribbean Site 999 are most likely due to a $1.0^{\circ}-1.2^{\circ} \mathrm{C}$ lower temperature in the deep Atlantic from $7.6 \mathrm{Ma}$ on. Surprisingly, the oxygen isotope record of North Atlantic Site 982 does not show the early Messinian increase in $\delta^{18} \mathrm{O}$. The $\delta^{18} \mathrm{O}$ values, which were nearly identical to those of Site 926 before 7.0 Ma, remain at about the same level during the late Miocene and therefore exhibit intermediate values between those of Sites 999 and 926.

[14] The late Miocene $\delta^{13} \mathrm{C}$ values of Site 999 vary between $-0.3 \%$ and $1.2 \%$ in a range much larger than the one known from the late Pleistocene [Oppo et al., 1995]. The $\delta^{13} \mathrm{C}$ record shows distinct 100 -kyr cycles which are coherent with the variations in the 100-kyr band of the summer insolation at $65^{\circ} \mathrm{N}$ (Figure 2, bottom). Comparison to the $\delta^{13} \mathrm{C}$ record of Site 926 gives an excellent correlation between the two records, although Site 999 values are generally $0.6 \%$ lower. This difference is consistent with the modern gradient between Southern and northern component water masses. However, while the long-term gradient between the Caribbean and Atlantic records remains nearly constant throughout the late Miocene, there are changes in the gradient on orbital timescales. Short-term $\delta^{13} \mathrm{C}$ minima of Site 926 approaching the values of Site 999 occur regularly every $100 \mathrm{kyr}$, with a minimum difference close to each maximum in eccentricity (Figure 4a). Like in the $\delta^{18} \mathrm{O}$ record, Site 982 also exhibits nearly congruent $\delta^{13} \mathrm{C}$ values compared to Site 926 but slightly diverging toward lower values from
7.0 $\mathrm{Ma}$ on, reaching an intermediate level between Sites 999 and 926 records.

[15] To obtain a better understanding of the long-term evolution of the Caribbean Sea deep circulation, the late Miocene isotope data of Site 999 investigated in this study have been extended into the Pliocene using data of Haug and Tiedemann [1998] for this site. This extended record is compared to the combined records of Site 925 (3.3-4.5 Ma [Billups et al., 1997] and Site 926 (1.0-2.6 Ma [Bickert et al., 1997b], 2.6-3.3 Ma and 4.5-5.0 Ma [Tiedemann and Franz, 1997], and 5.0-7.5 Ma [Shackleton and Hall, 1997]) (Figure 5). While the combined $\delta^{18} \mathrm{O}$ records are nearly parallel for the entire late Neogene except for a slight divergence between 4.6 and $3.4 \mathrm{Ma}$, the combined $\delta^{13} \mathrm{C}$ records exhibit much larger fluctuations in the gradient between the Caribbean and the deep Atlantic. Like in the late Miocene, several excursions of Site $926 \delta^{13} \mathrm{C}$ down to the level of Site 999 occur also after 5.3 Ma regularly at each maximum of eccentricity. These excursions last only on the order of less than a precessional period. After 4.6 Ma the gradient between the two records began to decrease, parallel to an increase in the percentage of the coarse fraction of Site 999. Haug and Tiedemann [1998] interpreted this pattern as evidence for enhanced ventilation of the deep Caribbean basins and hence better carbonate preservation. A crossing over of the $\delta^{13} \mathrm{C}$ records occurs at $3.2 \mathrm{Ma}$, associated with the first negative excursion of $\delta^{13} \mathrm{C}$ in Site 926 that is related to a maximum in $\delta^{18} \mathrm{O}$, indicating the decrease of NADW production because of the intensification of the Northern Hemisphere glaciation. However, these climate changes do not affect the $\delta^{13} \mathrm{C}$ in the Caribbean. Instead, Caribbean Sea benthic $\delta^{13} \mathrm{C}$ in the late Neogene seems to reflect rather global $\delta^{13} \mathrm{C}$ changes.

\section{Discussion}

\subsection{Late Miocene Carbon Isotope Shift}

[16] In Site 999 as well as in Sites 982 and $926, \delta^{13} \mathrm{C}$ values continuously decreased by about $0.5 \%$ between 7.6 and 6.8 Ma. This decrease has been observed in many benthic as well as planktonic records of the world oceans [e.g., Wright et al., 1991; Hodell et al., 1994; Wright and Miller, 1996; Shackleton and Hall, 1997; Hodell et al., 2001; Billups, 2002]. Hence this carbon isotope shift has been interpreted to reflect a global decrease in the $\delta^{13} \mathrm{C}$ of the ocean's dissolved inorganic carbon pool. A number of authors have proposed that this carbon isotope shift resulted from increased erosion of organic carbon from terrigenous soils and shelf sediments during a drop in sea level as a result of Antarctic glaciation [e.g., Berger and Vincent, 1986]. Assuming an oceanic carbon mass of $38,000 \mathrm{Gt}$ [Schlesinger, 1991] and an average $\delta^{13} \mathrm{C}$ value of terrestrial organic carbon of $-25 \%$, the carbon shift could be explained by the transfer of about $760 \mathrm{Gt}$ of organic carbon from the terrestrial to the oceanic reservoir, which is about one third of the today's terrestrial carbon pool.

[17] Another hypothesis is derived from an observed change in the carbon isotope composition of paleosol carbonate nodules between 8 and 6 Ma [Cerling et al., 1997]. The change in terrestrial $\delta^{13} \mathrm{C}$ is in the opposite direction to the marine carbon shift and has been interpreted 

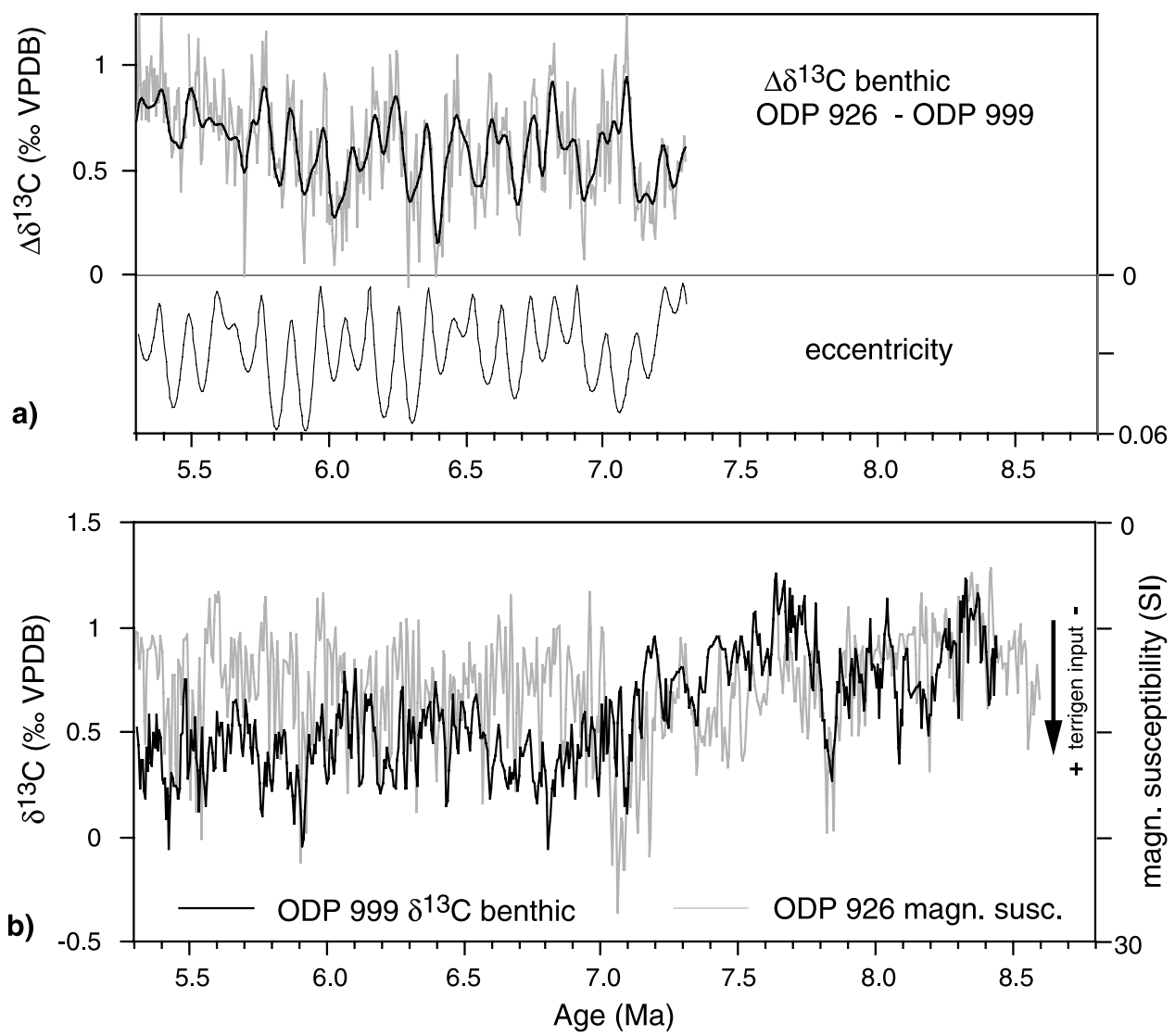

Figure 4. (a) Late Miocene difference between the deep Atlantic (Site 926) and deep Caribbean (Site 999) carbon isotope records and its variability in the 100-kyr frequency band (Gaussian filter centered at $10 \pm 3$ cycles $\mathrm{Myr}^{-1}$ ) compared to Earth orbital eccentricity. (b) Late Miocene benthic foraminiferal carbon isotope record of ODP Site 999 compared to the orbitally tuned magnetic susceptibility record of Site 926 [Shackleton and Crowhurst, 1997].

to reflect the shift from $\mathrm{C}_{3}$ - to $\mathrm{C}_{4}$-dominated ecosystems. This change was accompanied by an overall decrease in global biomass, which may have caused the marine decrease in $\delta^{13} \mathrm{C}$ values during the late Miocene. The expansion of grassland habitats and $\mathrm{C}_{4}$ plants may have been related to increased aridity. Such a change toward drier climate during the late Miocene is indicated by palynological evidence [e.g., Quade et al., 1989].

[18] A third hypothesis is drawn from changes in the oceanic $\delta^{13} \mathrm{C}$ as a result of variations in the ratio of inorganic to organic carbon contributed to sediments [Derry and France-Lanord, 1996]. A relative increase in the burial of organic carbon would preferentially remove ${ }^{12} \mathrm{C}$ from seawater so that the ocean reservoir would become isotopically heavier, and vice versa. The strong increase in the accumulation of biogenic sediments in the eastern equatorial Pacific between 7.5 and 6.7 Ma [Farrell et al., 1995] would support such a mechanism.

[19] The new late Miocene data set of the Caribbean Sea combined with the previously published carbon isotope records calls for an increased terrigenous input as the main process responsible for the late Miocene carbon isotope shift. Figure $4 b$ shows a comparison of the Site 999 carbon isotope record and the magnetic susceptibility record of Site 926 from the Ceara Rise. The magnetic susceptibility at the deep Atlantic site is assumed to reflect the varying dilution of marine carbonate oozes with terrigenous material delivered by the nearby Amazon River [e.g., Bickert et al., 1997a]. High susceptibility values indicate a high relative fraction of terrigenous sediments. The remarkable inverse correlation of the $\delta^{13} \mathrm{C}$ and the magnetic susceptibility records between 8.5 and $6.8 \mathrm{Ma}$, which also covers the interval of the carbon isotope shift, gives a hint of the influence of the terrigenous input on the $\delta^{13} \mathrm{C}$ of the ocean's dissolved inorganic carbon pool. Furthermore, the increase in $\delta^{18} \mathrm{O}$ values in the Caribbean record of Site 999 as well as in the deep Atlantic record of Site 926 coincident with the decrease in benthic foraminiferal $\delta^{13} \mathrm{C}$ is compatible with the association of an Antarctic ice volume increase and hence a higher continental weathering at the time of the carbon isotope shift. Finally, the increase in global ocean $\delta^{13} \mathrm{C}$ goes along with an increase in the intensity of carbonate dissolution at Ceara Rise [Murray and Peterson, 1997; King et al., 1997]. Together with similar observations from the deep equatorial Pacific [Berger et al., 1993], this implies that the carbon isotope shift was the result of an increase in the oceanic carbon inventory. 

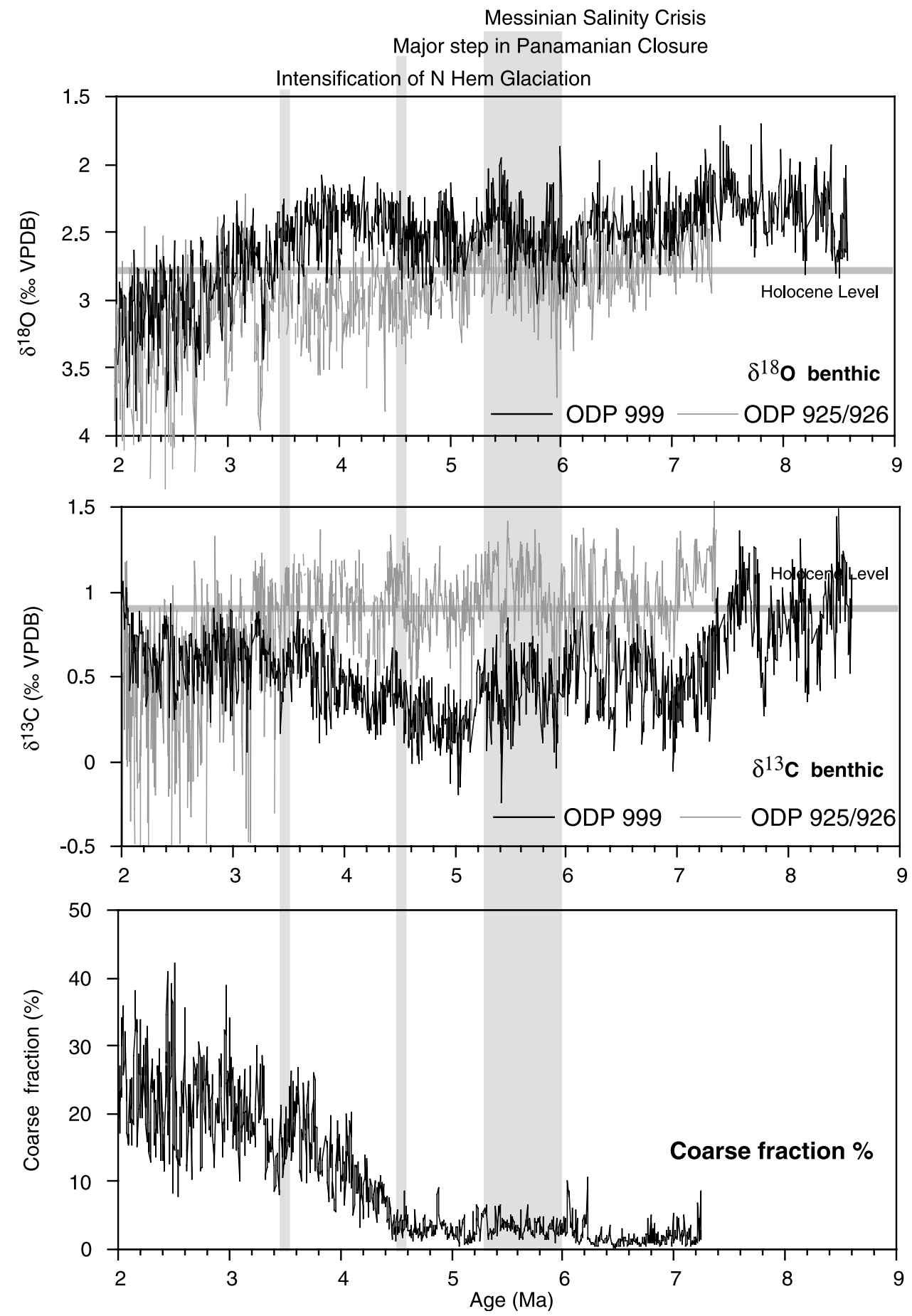

Figure 5. Benthic foraminiferal oxygen and carbon isotope and coarse fraction records of ODP Site 999 between 8.5 and 2.0 Ma (the Pliocene data are adopted from Haug and Tiedemann [1998]) compared to the combined isotope records of Site 925 (3.3-4.5 Ma [Billups et al., 1997]) and Site 926 (1.0-2.6 Ma [Bickert et al., 1997b], 2.6-3.3 Ma and 4.5-5.0 Ma [Tiedemann and Franz, 1997], and 5.0-7.5 Ma [Shackleton and Hall, 1997]).

[20] However, changes in late Miocene Atlantic to Pacific gradients in carbon isotopes suggest that the deep Atlantic became nutrient-depleted relative to the deep Pacific at about the same time interval (Figure 6). Site-to-site comparisons between the intermediate North Atlantic (Site 982), the deep equatorial Atlantic (Sites 925 and 926), the deep
Caribbean (Site 999), and the deep equatorial Pacific (Sites 289 and 849) exhibit a low gradient between the Atlantic and the Pacific until 7.6 Ma. Between 7.6 and 6.8 Ma a divergence between the Atlantic and Caribbean sites on one hand and the Pacific sites on the other hand indicates the development of the interoceanic gradients known from the 


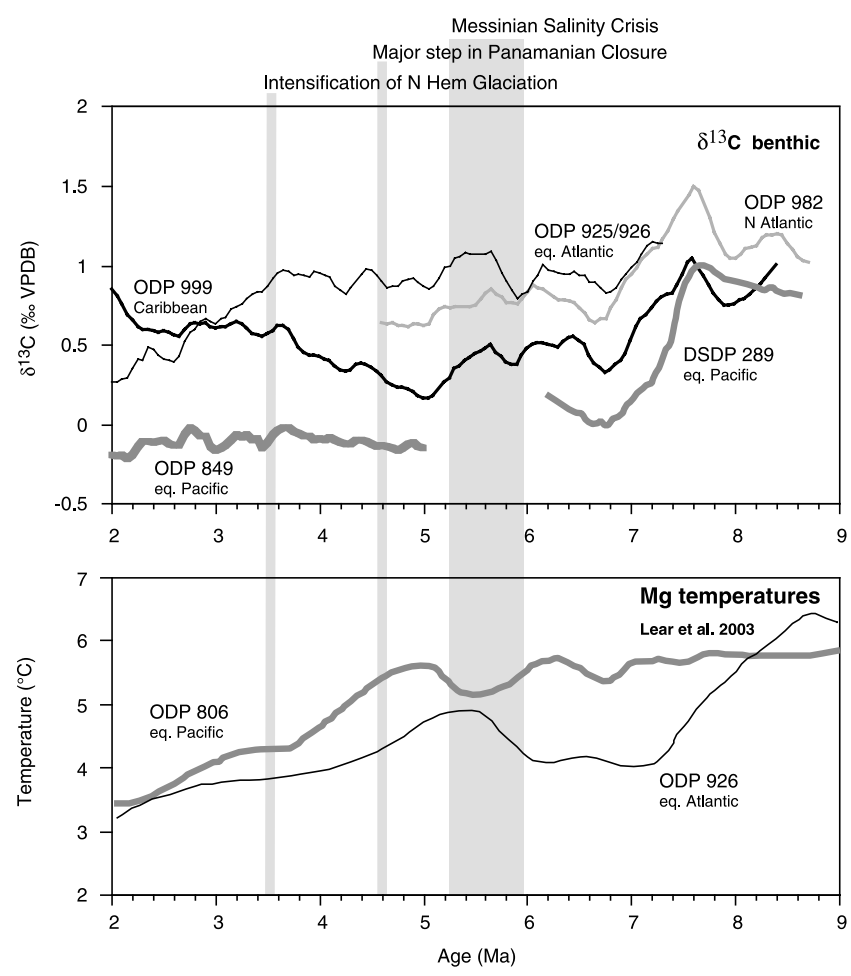

Figure 6. Late Miocene to Pliocene smoothed (using a $10 \%$ Gaussian distribution) benthic carbon isotope records of different sites representing the intermediate North Atlantic (Site 982 [Hodell et al., 2001]), the deep equatorial Atlantic (Sites 925 and 926 [Bickert et al., 1997b; Billups et al., 1997; Tiedemann and Franz, 1997; Shackleton and Hall, 1997]), the equatorial Pacific (Site 289 [Wright et al., 1991] and Site 849 [Mix et al., 1995]), and the Caribbean (Site 999, this study). These trends are compared to the deep water Mg-temperatures of the deep Atlantic (Site 926) and Pacific (Site 806) published by Lear et al. [2003].

modern ocean. This gives evidence for a NADW production prior to the final closing of the Isthmus of Panama. Billups [2002] stated from a similar compilation that the impact of an emerging Central American Isthmus on Atlantic to Pacific upper water exchange may have been felt in the North Atlantic beginning between 6.6 and 6.0 Ma. From our new carbon isotope record of the deep Caribbean we would state that this strengthening in deep Atlantic overturning started between 7.6 and $6.8 \mathrm{Ma}$, parallel to the carbon isotope shift, which is about $1 \mathrm{Myr}$ earlier than previously thought. However, the ventilation of the deep Caribbean Sea, as obtained from the increase in Site $999 \delta^{13} \mathrm{C}$ relative to the deep Pacific end-member, starts at 4.6 Ma, as shown by Haug and Tiedemann [1998]. From benthic foraminiferal $\mathrm{Mg} / \mathrm{Ca}$ records at equatorial Atlantic Site 926 and equatorial Pacific Site 806, Lear et al. [2003] derived that from $8.8 \mathrm{Ma}$ the Atlantic deep water temperature decreased by $1^{\circ}-2^{\circ} \mathrm{C}$ from the water mass filling the Atlantic basin before. Assuming the $\mathrm{Mg} / \mathrm{Ca}$ ratio in the oceans to have been unaffected by the calcite saturation changes during the late Miocene, the development of the modern deep water circulation was associated with the initiation of a relatively cold precursor of the NADW. The subsequent warming of this proto-NADW perhaps prohibited Northern Hemisphere ice growth in the early Pliocene [Lear et al., 2003].

\subsection{Origin of the $\mathbf{1 0 0 - k y r}$ Cyclicity}

[21] The occurrence of a 100-kyr cycle during most of the Neogene is yet not clearly understood. In the astronomical theory of climate the 100-kyr cycle (i.e., all cycles in the frequency band between $1 / 125$ and $1 / 95 \mathrm{kyr}^{-1}$, usually related to the eccentricity of the Earth's orbit) occupies the most intriguing place. Although it is the dominant cycle recorded by many paleoclimatic proxies, it is difficult to explain it in terms of a direct response to forcing by eccentricity. For the well-established appearance of these cycles in the late Pleistocene, nonlinear feedbacks resulting from different time constants for the growth and decay of ice sheets, as well as ice sheet/bedrock dynamics and an asymmetry of the obliquity cycles, have been discussed as possible causes for the prominent response of Earth's climate in this frequency band (for a review, see Imbrie et al. [1993]). However, in the late Miocene $\delta^{18} \mathrm{O}$ record of Site 999, as well as in many other records of this time interval, there is no evidence for large ice volume fluctuations in the Antarctic that belong to the 100 -kyr period. Furthermore, 100-kyr cyclicity has also been found in various records from presumably nonglacial periods like the Cretaceous [e.g., Herbert and Fischer, 1986]. The question thus arises as to what are the responsible mechanisms for climate response at this frequency band.

[22] Band-pass filtering of the $\delta^{13} \mathrm{C}$ record of Site 999 (using a Gaussian filter centered to the frequency $10 \pm$ 3 cycles $\mathrm{Myr}^{-1}$ ) shows significant amplitude variations corresponding to the major terms of the same frequency band in Northern Hemisphere summer insolation calculated using the astronomical solution by Laskar [1990]. As the average time resolution of the $\delta^{13} \mathrm{C}$ record is $4.05 \mathrm{kyr}$ (which is far below the precessional periods of 19 and $23 \mathrm{kyr}$ ), the 100-kyr cycle found in the series is no artifact from sample aliasing in the precession frequency band. It is apparent in Figure 2 that the 100-kyr cycle corresponds to even small amplitude variations in the filtered insolation record. As for the long-term carbon isotope shift, we propose that a large part of the 100-kyr cyclicity in the $\delta^{13} \mathrm{C}$ record of Site 999 reflects global changes in the $\delta^{13} \mathrm{C}$ of the dissolved inorganic carbon which result from changing terrigenous input to the oceans. The magnetic susceptibility record of Site 926 from the Ceara Rise also exhibits in the 100-kyr frequency band a relatively high coherence $\left(r^{2}=0.56\right)$ with the $\delta^{13} \mathrm{C}$ record of Site 999 (Figure $\left.4 \mathrm{~b}\right)$. The strong evidence of a 100-kyr cycle in the terrigenous input might be explained by the influence of the Earth's axial precession on the intensity of trade winds and hence the precipitation and weathering intensity over the South American continent [e.g., Harris and Mix, 1999]. Since the eccentricity of the Earth's orbit modulates the precessional effect on insolation, there is a transfer of the 100-kyr cycle to the tropical climate systems and thus to the sedimentary pattern of the late Miocene. However, the question arises as to why the $\delta^{13} \mathrm{C}$ record of Site 999 shows a strong response to eccentricity but not a similar strong response to precession. The dominance of the $100-\mathrm{kyr}$ cycle has been also 
obtained from other sedimentary climate records adjacent to tropical South America during the Pliocene and early Pleistocene. Harris and Mix [1999] deduced climatic changes from the Amazon lowland iron oxides and explained the strong $100-$ kyr cycles in precipitation by latitudinal shifts of the Intertropical Convergence Zone driven by a nonlinear amplification of insolation forcing at precessional amplitudes. A similar nonlinear response might have driven the predominance of the 100-kyr cycle in the carbon isotope record. However, the terrigenous matter supply recorded at Ceara Rise gives clear evidence for the influence of precession itself [Shackleton and Crowhurst, 1997].

[23] A minor part of the carbon isotope 100-kyr cyclicity at Site 999 might also be attributed to changes in the deep water exchange between the Caribbean and the deep Atlantic. Changes in the $\delta^{13} \mathrm{C}$ difference between the records of Sites 999 and 926 occur at each maximum of eccentricity between 7.0 and $4.5 \mathrm{Ma}$, when $\delta^{13} \mathrm{C}$ minima at Site 926 approach those of Site 999 (Figure 4a). Such a pattern might indicate a reduced ventilation of the deep Atlantic, caused by a reduction of northern component water at that time. This phenomenon is coincident with generally higher $\delta^{18} \mathrm{O}$ values during that time (Figure 2). Estimated Miocene ice volume, inferred from these $\delta^{18} \mathrm{O}$ changes, is assumed to fluctuate between 60 and $90 \%$ of the modern Antarctic ice sheet [Wright et al., 1992]. It is possible that during the late Miocene the $100-\mathrm{kyr}$ cycle in the $\delta^{13} \mathrm{C}$ gradient was amplified during times of glacial intensification. However, as stated above, in contrast to the Pleistocene, there were no 100-kyr fluctuations in the Antarctic ice volume at that time.

\subsection{Late Miocene Caribbean Deep Circulation}

[24] A final question remains as to whether circulation changes in the Caribbean Sea were in any way affected by the Messinian Salinity Crisis. For that purpose, the epibenthic $\delta^{13} \mathrm{C}$ record of ODP Site 1006 [McKenzie et al., 1999] has been added to those of Sites 926 and 999 (Figure 7). Site 1006 was drilled at the deep end $(658 \mathrm{~m}$ water depth) of a transect across the western flank of the Great Bahama Platform and is thought to represent the ventilation of the northern Caribbean basins, which are separated from the Columbian Basin by the Northern Nicaragua Rise with a modern sill depth of $1400 \mathrm{~m}$ within the Pedro Channel (Figure 1). Before 6.0 Ma, high $\delta^{13} \mathrm{C}$ values at Site 1006 indicate well-oxygenated conditions in the shallow northern Caribbean Sea, except for some negative excursions at times of eccentricity maxima. Between 6.0 and 5.6 Ma, a period marked by reduced inflow of ocean water to the Mediterranean Sea and initial deposition of evaporative sequences, a decrease in $\delta^{13} \mathrm{C}$ provides a hint of change in the Caribbean region, but a large gap in Site 1006 record prevents a better view of this time interval. Between 5.6 and 5.3 Ma, which marks the period of complete isolation of the Mediterranean Sea and deposition of the Lago Mare facies, minimum values in $\delta^{13} \mathrm{C}$ occur in the Site 1006 record, which are close to the level of Site 999 values. Hence, during the culmination of the Messinian Salinity Crisis, which is thought to be caused by a sea level low stand at that time [Zhang and Scott, 1996], the entire
Caribbean Sea was poorly ventilated. At $5.3 \mathrm{Ma}$, the $\delta^{13} \mathrm{C}$ values at Site 1006 increase to the deep Atlantic level, which indicates the reestablishment of the overflow over the Northern Nicaragua Rise to the northern Caribbean. However, studies of nannofossil assemblages suggest that surface circulation was not affected by these late Miocene to early Pliocene intermediate and deep water changes [Kameo and Sato, 2000].

[25] How can the coincidence between the ventilation of the Florida Strait and the isolation of the Mediterranean be explained? We assume that local tectonics related to the Northern Nicaragua Rise may have set the sill depth such that this deep water passage became a discriminating valve for inflowing open ocean water, similar to the Isthmus of Gibraltar at that time. A lower sea level during the late Messinian, which is assumed to have caused the reduced inflow into the Mediterranean Basin, might also have reduced the overflow into the northern Caribbean. A transgression at 5.3 Ma should have therefore not only flooded the Mediterranean but also led to a better ventilation of the northern Caribbean basin. This flooding event is consistent with the observed rapid back stepping of reefs on the Bahama platform [Eberli et al., 1997].

[26] During the early Pliocene, negative $\delta^{13} \mathrm{C}$ excursions arise, which affected not only the Florida Strait (Site 1006) but also the entire water column of the Atlantic and hence the Caribbean (i.e., the records of Sites 926, 982, and 999) at the same time. At least two of these events, at 5.17 and $4.84 \mathrm{Ma}$, are related to significant drop downs in the benthic $\delta^{18} \mathrm{O}$ (Figure 5). These events are therefore interpreted as changes in thermohaline circulation, i.e., reductions of NADW, caused by continental glaciations, and they might be seen as precursors of abrupt circulation changes known to be common in the late Pleistocene.

\section{Conclusions}

[27] The main conclusions of this study include the following:

[28] 1. Low epibenthic $\delta^{13} \mathrm{C}$ values and low percentages of sand-sized particles (mostly foraminifer shells) recorded between 8.5 and 5.3 Ma in the sediment sequences of ODP Site 999 indicate a poorly ventilated deep Caribbean Sea throughout the late Miocene. At this time the deep Caribbean was dominated by a nutrient-rich and corrosive water mass.

[29] 2. A generally constant $\delta^{13} \mathrm{C}$ gradient between the Caribbean and deep Atlantic records during the late Miocene suggests that the fluctuations in $\delta^{13} \mathrm{C}$ reflect global rather than local changes in $\delta^{13} \mathrm{C}$ of the dissolved inorganic carbon. We interpret these to be due to varying erosion of organic carbon from terrigenous soils and shelf sediments. The observed $100-$ kyr cyclicity of epibenthic $\delta^{13} \mathrm{C}$ is in good accordance with the variability of the terrigenous input to the equatorial Atlantic as recorded by magnetic susceptibility records of the Ceara Rise.

[30] 3. Some short-term $\delta^{13} \mathrm{C}$ gradient changes between 7.0 and $4.5 \mathrm{Ma}$, all related to maxima in eccentricity, indicate a poorer ventilation of the deep Atlantic and may be attributed to a lower production of deep water in the Atlantic. 


\begin{tabular}{|c|c|}
\hline PLIOCENE & MIOCENE \\
\hline Zanclean & Messinian \\
\hline
\end{tabular}

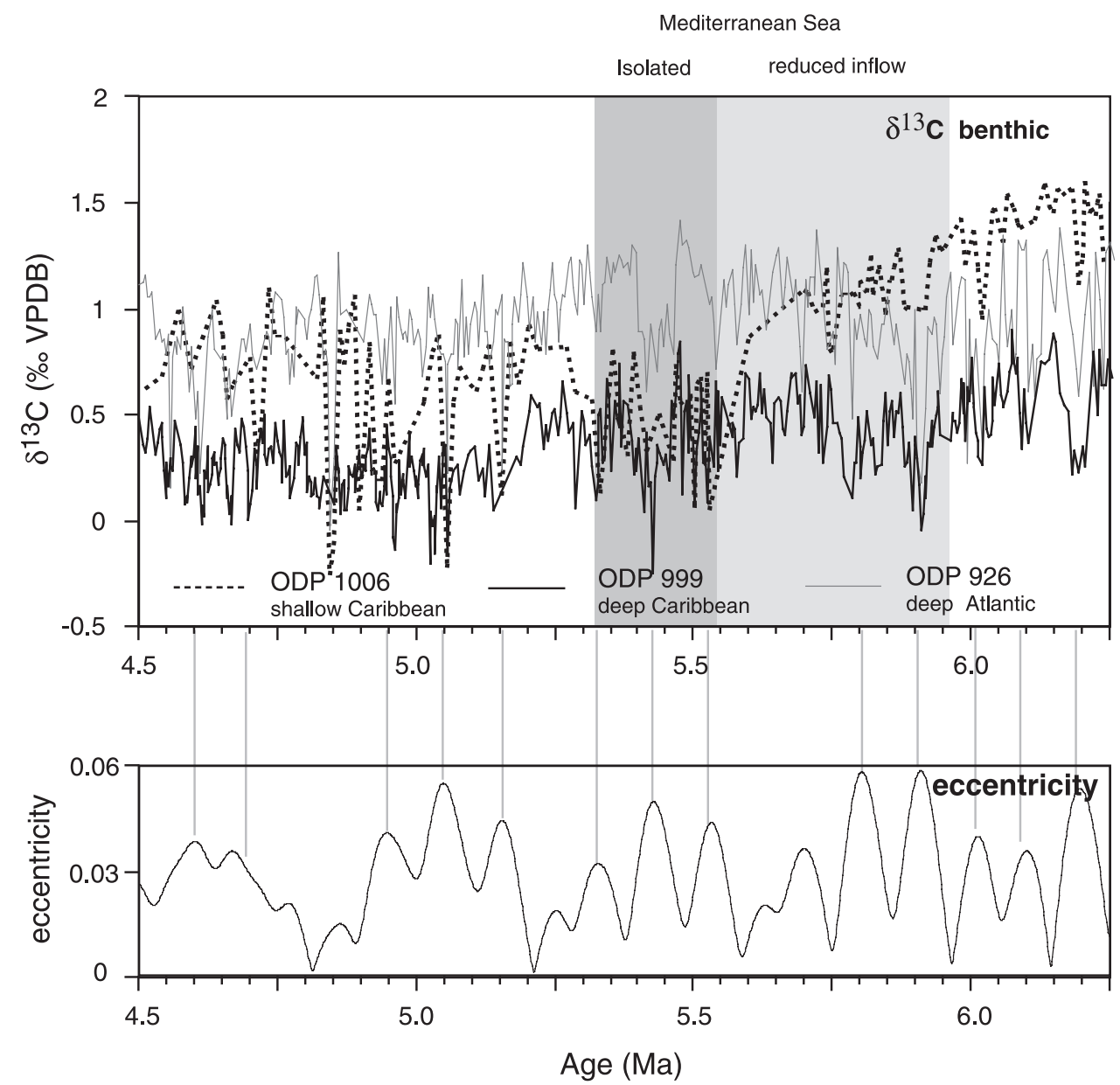

Figure 7. Benthic foraminiferal $\delta^{13} \mathrm{C}$ records of the shallow (Site 1006) and deep (Site 999) Caribbean Sea and the deep equatorial Atlantic (Site 926) compared to the record of Earth orbital eccentricity calculated by using the astronomical solution of Laskar [1990].

[31] 4. The Messinian Salinity Crisis between 6.0 and 5.3 Ma did not affect the intermediate to deep water gradient between the Caribbean and the Atlantic. Comparison to the Bahama platform record of ODP Site 1006, however, indicates a poorer ventilation of the shallower northern Caribbean basins coincident with the isolation of the Mediterranean Sea.
[32] Acknowledgments. The authors are indebted to Monika Segl, who carefully supervises the operation of the mass spectrometers of the Fachbereich Geowissenschaften, University of Bremen. We would like to thank the Larry Peterson, William Chaisson, and an anonymous reviewer for valuable comments to the manuscript. This research used samples and data provided by the Ocean Drilling Program, which is sponsored by the U.S. National Science Foundation and participating countries under management of Joint Oceanographic Institutions. Funding for this research was provided by the Deutsche Forschungsgemeinschaft (We 992/21).

\section{References}

Backman, J., and I. Raffi (1997), Calibration of Miocene nannofossil events to orbitally tuned cyclostratigraphies from Ceara Rise, Proc. Ocean Drill. Program Sci. Results, 154, $83-$ 100 .

Berger, W. H., and E. Vincent (1986), Deep-sea carbonates: Reading the carbon-isotope signal, Geol. Rundsch., 75, 249-269.

Berger, W. H., M. C. Bonneau, and F. L. Parker (1982), Foraminifera on the deep-sea floor:
Lysocline and dissolution rate, Oceanol. Acta, $5,249-258$.

Berger, W. H., R. M. Leckie, T. R. Janecek, R. Stax, and T. Takayama (1993), Neogene carbonate sedimentation on Ontong Java Plateau: Highlights and open questions, Proc. Ocean Drill. Program Sci. Results, 130, $711-744$.

Bickert, T., R. Cordes, and G. Wefer (1997a), Late Pliocene to middle Pleistocene (2.6 to
1.0 Ma) carbonate dissolution in the western equatorial Atlantic: Results of Leg 154, Ceara Rise, Proc. Ocean Drill. Program Sci. Results, 154, 229-237.

Bickert, T., W. B. Curry, and G. Wefer (1997b), Late Pliocene to Holocene (2.6 to $0 \mathrm{Ma}$ ) western equatorial Atlantic deep water circulation: Inferences from benthic stable isotopes, Leg 154, Proc. Ocean Drill. Program Sci. Results, $154,239-254$. 
Billups, K. (2002), Late Miocene through early Pliocene deep water circulation and climate change viewed from the sub-Antarctic South Atlantic, Palaeogeogr. Palaeoclimatol. Palaeoecol., 185, 287-307.

Billups, K., A. C. Ravelo, and J. C. Zachos (1997), Early Pliocene deep-water circulation: Stable isotope evidence for enhanced Northern Component Deep Water, Proc. Ocean Drill. Program Sci. Results, 154, 319-330.

Billups, K., A. C. Ravelo, and J. C. Zachos (1999), Link between oceanic heat transport, thermohaline circulation and the Intertropical Convergence Zone in the early Pliocene Atlantic, Geology, 27, 319-322.

Cerling, T. E. J., J. H. Harris, B. J. MacFadden, M. G. Leaky, J. Quade, V. Eisenmann, and J. R. Ehleringer (1997), Global vegetation change through the Miocene/Pliocene boundary, Nature, 389, 153-158.

Derry, L. A., and C. France-Lanord (1996), Neogene growth of the sedimentary organic carbon reservoir, Paleoceanography, 11, 267-276.

Driscoll, N. W., and J. B. Diebold (1999), Tectonic and stratigraphic development of the eastern Caribbean: New constraints from multichannel seismic data, in Sedimentary $\mathrm{Ba}$ sins of the World, vol. 4, Caribbean Basins, edited by P. Mann, pp. 591-626, Elsevier Sci., New York.

Droxler, A. W., K. Burke, A. D. Cunningham, A. C. Hine, E. Rosencrantz, D. S. Duncan, P. Hallock, and E. Robinson (1998), Caribbean constraints on circulation between Atlantic and Pacific Oceans over the past 40 million years, in Tectonic Boundary Conditions for Climate Reconstruction, Oxford Monogr. Geol. Geophys., vol. 39, edited by T. J. Crowley and K. C. Burke, pp. 160-191, Oxford Univ. Press, New York.

Duplessy, J. C., N. J. Shackleton, R. K. Matthews, W. Prell, W. F. Ruddiman, M. Caralp, and C. H. Hendy (1984), ${ }^{13} \mathrm{C}$ record of benthic foraminifera in the last interglacial ocean: Implications for the carbon cycle and the global deep water circulation, Quat. Res., 21, $225-243$.

Duque-Caro, H. (1990), Neogene stratigraphy, paleoceanography and paleobiogeography in northwest South America and the evolution of the Panama Seaway, Palaeogeogr. Palaeoclimatol. Palaeoecol., 77, 203-234.

Eberli, G. P., P. K. Swart, D. F. McNeill, J. A. M. Kenter, F. S. Anseimetti, L. A. Melim, and R. N. Ginsburg (1997), A synopsis of the Bahamas Drilling Project: Results from two deep core borings drilled on the Great Bahma Bank, Proc. Ocean Drill. Program Sci. Results, 166, 23-41.

Farrell, J. W., I. Raffi, T. R. Janecek, T. R. Murray, M. Levitan, K. A. Dadey, K. C. Emeis, M. Lyle, J. A. Flores, and S. Hovan (1995), Late Neogene sedimentation patterns in the eastern equatorial Pacific Ocean, Proc. Ocean Drill. Program Sci. Results, 138, 717-756.

Haddad, G. A., and A. W. Droxler (1996), Metastable $\mathrm{CaCO}_{3}$ dissolution at intermediate water depths of the Caribbean and western North Atlantic: Implications for intermediate water circulation during the past 200,000 years, Paleoceanography, 11, 701-716.

Harris, S. E., and A. C. Mix (1999), Pleistocene precipitation balance in the Amazon basin recorded in deep sea sediments, Quat. Res., 51, 14-26.

Haug, G. H., and R. Tiedemann (1998), Effect of the formation of the Isthmus of Panama on Atlantic Ocean thermohaline circulation, Nature, 393, 673-675.
Haug, G. H., R. Tiedemann, R. Zahn, and A. C. Ravelo (2001), Role of Panama uplift on oceanic freshwater balance, Geology, 29, 207-210.

Herbert, T. D., and A. G. Fischer (1986), Milankovitch climatic origin of mid-Cretaceous black shale rhythms in central Italy, Nature, $321,739-743$

Hodell, D. A., R. H. Benson, D. V. Kent, A. Boersma, and K. Rakic-El Bied (1994), Magnetostratigraphic, biostratigraphic, and stable isotope stratigraphy of an upper Miocene drill core from the Salé Briqueterie (northwestern Morocco): A high-resolution chronology for the Messinian stage, Paleoceanography, 9, 835-856.

Hodell, D. A., J. H. Curtis, F. J. Sierro, and M. E. Raymo (2001), Correlation of late Miocene to early Pliocene sequences between the Mediterranean and North Atlantic, Paleoceanography, $16,164-178$.

Hsü, K. J., M. B. Cita, and W. B. F. Ryan (1973), Late Miocene desiccation of the Mediterranean, Nature, 242, 240-244.

Imbrie, J., et al. (1993), On the structure and origin of major glaciation cycles: 2 . The 100,000year cycle, Paleoceanography, 8, 699-735.

Jackson, J. B. C., A. G. Jung, A. G. Coates, and L. G. Collins (1993), Diversity and extinction of tropical American mollusks and emergence of the Isthmus of Panama, Science, 260, $1622-1624$

Kameo, K., and T. Sato (2000), Biogeography of Neogene calcareous nannofossils in the Caribbean and the eastern equatorial Pacific-floral response to the emergence of the Isthmus of Panama, Mar. Micropaleontol. 39, 201-218.

Keigwin, L. D. (1982), Isotopic paleoceanography of the Caribbean and east Pacific: Role of Panama uplift on late Neogene time, Science, 217, 350-353.

Keller, G., C. Zenker, and S. Stone (1989), Late Neogene history of the Pacific Caribbean gateway, J. S. Am. Earth Sci., 2, 73-108.

King, T. A., W. G. Ellis, D. W. Murray, N. J. Shackleton, and S. Harris (1997), Miocene evolution of carbonate sedimentation at the Ceara Rise: A multivariate data/proxy approach, Proc. Ocean Drill. Program Sci. Results, 154, 349-365.

Krijgsman, W., F. J. Hilgen, I. Raffi, F. J. Sierro, and D. S. Wilson (1999), Chronology, causes and progression of the Messinian Salinity Crisis, Nature, 400, 652-655.

Laskar, J. (1990), The chaotic motion of the solar system: A numerical estimate of the size of the chaotic zones, Icarus, 88, 266-291

Lear, C. H., Y. Rosenthal, and J. D. Wright (2003), The closing of a seaway: Ocean water masses and global climate change, Earth Planet. Sci. Lett., 210, 425-437.

Mackensen, A., and T. Bickert (1999), Stable carbon isotopes in benthic foraminifera: Proxies for deep and bottom water circulation and new production, in Use of Proxies in $\mathrm{Pa}$ leoceanography: Examples From the South Atlantic, edited by G. Fischer and G. Wefer, pp. 229-254, Springer-Verlag, New York.

McKenzie, J. A., S. Spezzaferri, and A. Isern (1999), The Miocene-Pliocene boundary in the Mediterranean Sea and Bahamas: Implications for a global flooding event in the earliest Pliocene, Mem. Soc. Geol. Ital., 54, 93-108.

Mikolajewicz, U., and T. J. Crowley (1997), Response of a coupled ocean/energy balance model to restricted flow through the central American isthmus, Paleoceanography, 12, $429-441$.
Mix, A. C., N. G. Pisias, W. Rugh, J. Wilson, A. Morey, and T. K. Hagelberg (1995), Benthic foraminifer stable isotope record from Site 849 (0-5 Ma): Local and global changes, Proc. Ocean Drill. Prog. Sci. Results, 138, 371-412.

Murray, D. W., and L. C. Peterson (1997), Biogenic carbonate production and preservation changes between 5 and $10 \mathrm{Ma}$ from the Ceara Rise, western equatorial Atlantic, Proc. Ocean Drill. Program Sci. Results, 154, 375-388.

Oppo, D. W., M. E. Raymo, G. P. Lohmann, A. C. Mix, J. D. Wright, and W. L. Prell (1995), A $\delta^{13} \mathrm{C}$ record of Upper North Atlantic Deep Water during the past 2.6 million years, Paleoceanography, 10, 373-394.

Quade, J., T. E. Cerling, and J. R. Bowman (1989), Development of Asian monsoon revealed by marked ecological shift during the latest Miocene in northern Pakistan, Nature, 342, $163-166$.

Ryan, W. B. F. (1973), Geodynamic implications of the Messinian crisis of salinity, in Messinian Events in the Mediterranean, edited by $\mathrm{C}$. W. Drooger, pp. 26-38, North-Holland, New York.

Schlesinger, W. H. (1991), Biogeochemistry: An Analysis of Global Change, 443 pp., Academic, San Diego.

Shackleton, N. J., and S. Crowhurst (1997), Sediment fluxes based on an orbitally tuned time scale $5 \mathrm{Ma}$ to $14 \mathrm{Ma}$, Site 926, Proc. Ocean Drill. Program Sci. Results, 154, 69-82.

Shackleton, N. J., and M. A. Hall (1997), The late Miocene stable isotope record, Site 926 , Proc. Ocean Drill. Program Sci. Results, 154, $367-374$.

Sigurdsson, H., et al. (1997), Proceedings of the Ocean Drilling Program, Initial Report, vol. 165, 865 pp., Ocean Drill. Program, College Station, Tex

Tiedemann, R., and S. O. Franz(1997), Deep water circulation, chemistry, and terrigenous sediment supply in the equatorial Atlantic during the Pliocene, 3.3-2.6 Ma and 5-4.5 Ma, Proc. Ocean Drill. Program Sci. Results, 154, 299-318.

Vidal, L., T. Bickert, U. Röhl, and G. Wefer (2000), Late Miocene stable isotope stratigraphy of SE Atlantic ODP Site 1085: Relation to Messinian events, Mar. Geol., 180, 71-85.

Wright, J. D., and K. G. Miller (1996), Control of North Atlantic Deep Water circulation by the Greenland-Scotland Ridge, Paleoceanography, 11, 157-169.

Wright, J. D., K. G. Miller, and R. G. Fairbanks (1991), Evolution of modern deepwater circulation: Evidence from the late Miocene Southern Ocean, Paleoceanography, 6, 275-290.

Wright, J. D., K. G. Miller, and R. G. Fairbanks (1992), Early and middle Miocene stable isotopes: Implications for deep water circulation and climate, Paleoceanography, 7 , $357-389$.

Zhang, J., and D. B. Scott (1996), Messinian deepwater turbidites and glacioeustatic sea-level changes in the North Atlantic: Linkage to the Mediterranean Salinity Crisis, Paleoceanography, 11, 277-298.

T. Bickert, Fachbereich Geowissenschaften, Universitaet Bremen, D-28334 Bremen, Germany. (bickert@uni-bremen.de)

G. H. Haug, GeoForschungsZentrum Potsdam, D-14473 Potsdam, Germany. (haug@gfzpotsdam.de)

R. Tiedemann, GEOMAR, Universitaet Kiel, D-24118 Kiel, Germany. (rtiedemann@geomar. de) 